\title{
KAPASITAS UIN ALAUDDIN MAKASSAR PASCA ALIH STATUS
}

\section{CAPACITY OF UIN ALAUDDIN MAKASSAR AFTER TRANSFER OF STATUS}

\author{
Muhammad Rais \\ Balai Penelitian dan Pengembangan Agama \\ Jl. Andi Pangeran Pettarani, No. 72 Makassar \\ Email: raispuslit2@gmail.com
}

Naskah diterima 10 Oktober 2017, direvisi 30 Oktober 2017, disetujui 6 November 2017

\begin{abstract}
This article describes the capacity and performance achievements of UIN Alauddin post-status change. This study uses qualitative methods with the data obtained through indepth interviews, observation and documentation studies. The results of this study shows that the capacity and performance of UIN Alauddin has increased, both from the interest and expectations of society and improved governance of institutional organizations, personnel, increasingly competitive infrastructure, increasingly proportional financing, learning, cooperation, and community service. Nevertheless, there are still a number of weaknesses and challenges, such as the process of institutional transformation is not working properly in terms of integration and interconnection of science, limited publication of research results through national and international journals.
\end{abstract}

Keywords: capacity, UIN Alauddin, transfer of status, Makassar

\begin{abstract}
Abstrak
Artikel ini mendeskripsikan tentang kapasitas dan capaian kinerja UIN Alauddin pasca alihstatus. Studi ini menggunakan metode kualitatif, sumber data diperoleh melalui wawancara mendalam, observasi dan studi dokumentasi. Hasil studi ini menemukan bahwa, kapasitas serta kinerja UIN Alauddin mengalami peningkatan, baik dari animo dan ekspektasi masyarakat. Selain itu, semakin membaiknya tata kelola organisasi kelembagaan, ketenagaan, infrastruktur yang semakin kompetitif, pembiayaan yang semakin proporsional, pembelajaran, kerjasama, dan pengkhidmatan pada masyarakat. Meskipun demikian, masih terdapat sejumlah kelemahan dan tantangan, misalnya proses transformasi institusional belum berjalan sebagaimana semestinya dalam hal intergrasi dan interkoneksi keilmuan, masih terbatasnya publikasi hasilhasil penelitian melalui jurnal nasional maupun internasional.
\end{abstract}

Kata kunci: kapasitas, UIN Alauddin, alih-status, Makassar 


\section{PENDAHULUAN}

Capaian performa serta mutu perguruan tinggi kita, masih dipertanyakan banyak kalangan, konon belakangan institusi pendidikan tinggi di Indonesia, justru semakin terdorong ke belakang karena kalah bersaing dengan perguruan tinggi di dunia. ${ }^{1}$ Alih-alih bersaing di tingkat global, hatta di kawasan regional ASEAN sekalipun, perguruan tinggi kita "tak banyak bicara". Ironisnya, di tengah tumpukan sorotan tersebut, sebagian perguruan tinggi kita malah ditengarai sebagai ladang korupsi sebagaiman yang dirilis Transparency International yang menyebut-sebagian kecilpendidikan (tinggi) di Indonesia diwarnai korupsi yang parah. ${ }^{2}$

Maka, tak ayal jika kemudian Daoed Joesoef, mantan Mendikbud periode 19781983, mengajak kita untuk melakukan refleksi, memikirkan ulang pendidikan sehubungan dengan tidak tumbuhnya komunitas ilmiah di perguruan tinggi kita (Kompas, 7/4/2014). Hendra Gunawan mengalaborasi kegalauan tokoh pendidikan modern Indonesia, ia mengemukakan

${ }^{1}$ Di level internasional, Times Higher Education juga memublikasi World University Rankings 20152016. Indonesia hanya berhasil menempatkan satu perguruan tinggi negeri (PTN): UI di urutan ke601-800. PTN kuat lain, seperti ITB, IPB, dan UGM, tak termasuk dalam daftar itu. Untuk level Asia Tenggara, National University of Singapore (NUS) dan Nanyang Technological University-keduanya dari Singapura-menduduki peringkat ke-1 dan ke-2. Malaysia menempatkan lima universitasnya (di peringkat ke-3, 5, 7, 8, dan ke-9), Thailand diwakili dua universitas (urutan ke-4 dan ke-6), dan Filipina satu universitas (posisi ke-10). Indonesia? Tak ada di posisi 10 besar. UI hanya menduduki tempat ke-11, dikutip dari Syamsul Rijal, (Kompas, 10/03/2016).

${ }^{2}$ Chris Parr, Times Higher Education, 4 Oktober 2013. bahwa, dalam konteks peningkatan daya saing bangsa, terlebih di abad ke-21 ini, lumbung benih itu adalah perguruan tinggi dan lembaga-lembaga penelitian yang mempelajari dan mengembangkan ilmu pengetahuan dan teknologi. Namun, belakangan ini kita juga tidak melihat adanya titik terang bahwa kita akan menikmati "panen" berlimpah 10-20 tahun ke depan. Investasi kita untuk masa depan itu sangat minim (Kompas, 02 Mei 2014)

UIN Alauddin sebagai salah satu bagian dari subsistem pendidikan nasional, tak lepas dari sorotan tersebut, sehingga ikhtiar untuk bertranformasi, sekaligus beradaptasi dengan kondisi kekinian, yang terepresentasi pada tuntutan publik akan peran-peran profetis instititusi pendidikan tinggi. Maka, wider mandate serta alih status secara kelembagaan IAIN/STAIN menjadi UIN merupakan solusi konstruktifnya, yang ditengarai sebagian kalangan sebagai upaya "lompatan quantum" dan mewakili reformasi pemikiran Islam Indonesia selama ini. Ia sebagai kelanjutan dari campuran antara keinginan, cita-cita, struggle, kecemasan, kegelisahan, dan optimisme dari tokoh-tokoh Islam (mewakili masyarakat Muslim dan puak cendekiawan Muslim) yang menginginkan lahirnya pendidikan tinggi Islam yang berwibawa di Indonesia ${ }^{3}$.

Ghirah untuk mengembangkan serta memperluas mandate perguruan tinggi Islam tadi, didorong oleh kesadaran akan keniscayan perguruan tinggi ini untuk bersaing, baik tingkat regional maupun secara global, namun, impian tersebut masih terkendala oleh beberapa faktor,

${ }^{3}$ Mustaki, www.pendis.kemenag. co, diunduh 01/01/2016 
salah satunya menurut A. Malik Fajar, pengarusutamaan pendidikan agama yang cenderung statis sehingga tidak marketable, dan kondisi ini akan menggiring ke wilayah peripheral. Maka, solusi konstruktif adalah wider mandate dan alih fungsi status kelembagaan menuju universitas berkualitas par excellence, guna mengantisipasi persaingan dengan perguruan tinggi umum di tingkat regional maupun kompetisi di tingkat global. Sebab, konteks kekinian menurut M. Idris (2010: 4001), IAIN/STAIN tidak memadai lagi dalam merespon tantangan globalisasi dan modernitas. Dan, di sisi lain, menurut Azra, ${ }^{4}$ IAIN/UIN melekat padanya dua harapan: social expectations dan academic expectations

Setali tiga uang dengan itu, Morin mengajukan "proposal" bahwa, pendidikankhususnya Pendidikan Tinggi-di masa depan dihadapkan pada masalah universal, proses pembelajaran dan organisasi pembelajaran kita masih cenderung sporadis, tidak komprehensif, terkotak-kotak, sehingga tidakmemadailagiuntukmenangkap realitas dan problematika yang semakin mengglobal, transnasional, multidimensional, transversal, interdisipliner dan berskala planeter. $^{5}$

Sejatinya, bangsa ini tidak kekurangan benchmarking bahkan best practices berkenaan dengan tata kelola perguruan tinggi, sebagaiman yang juga dirintis di Negara maju, sebab Negara ini masih dalam aneksasi imperialisme telah

\footnotetext{
${ }^{4}$ Asyumardi Azra, 2012. Pendidikan Islam: Tradisi dan Modernisasi di Tengah Tantangan Millenuim III, Jakarta: kencana Prenada Media, hlm. 196

${ }^{5}$ Lihat, Hanief Sahar Ghafur, 2009. Manajemen Mutu, Penjaminan dan Internasionalisasi Perguruan Tinggi di Indonesia, Jakarta: UI Press, hal. 1-2
}

"bertebaran" gagasan kongkret tentang tata kelola perguruan tinggi. Tengok misalnya, pandangan Soepomo bahwa, universitas sebagai opleidingsinstituut akan: (a) memberikan pendidikan pengetahuan dasar untuk mahasiswa dari fakultas mana pun agar mereka mendapatkan academische levensstijl', yakni mempunyai kecerdasan jiwa, budi, dan intelek yang diperlukan untuk jabatan-jabatan tinggi di tengah masyarakat, dan (b) memberikan persiapan untuk mengerjakan vak atau bidang keahlian tertentu, misalnya sebagai ahli hukum, dokter, dan insinyur (dalam Hendra Gunawan, Kompas, 26/10/2013). Namun, sayangnya, generasi di belakang merekasadar ataupun tidak sadar-sedari awal telah mengabaikan misi profetis tersebut. Maka, tidak heran jika performa perguruan tinggi kita tak mampu beranjak dari keterpurukan hingga kini.

Di tengah keterpurukan tersebut, beberapa cendekiawan Muslim avant garde mengambil langkah progresif untuk melakukan tajdid (pembaharuan) perguruan tinggi Islam yang selama ini terjebak dalam pusaran tranformasi keilmuan yang serba monolitik dan dikotomis, sebut misalnya Harun Nasution, A. Malik Fajar, Quraish Shihab, Imam Suprayogo, Azyumardi Azra, Azhar Arsyad, Nanath Fattah, dan seterusnya. Harapan dan impian, serta kerja ikhlas mereka pun tak bertepuk sebelah tangan. Sebab, tak berselang lama, seiring dengan putaran waktu, beberapa IAIN yang diusulkan untuk dikonversi pun akhirnya "berbuah manis." Hingga penelitian ini dilakukan tercatat telah ada 6 UIN yang eksis di Tanah Air dengan visi dan misi masingmasing. 
Mengacu pada deskripsi berkenaan dengan kondisi ideal dan sejatinya performa dan kualitas Perguruan Tinggi sebagaimana yang diproyeksikan, dengan jarak ketimpangan dengan realitas aktual yang mengitari institusi pendidikan tersebut, tak terkecuali institusi pendidikan Islam, maka pertanyaan riset yang urgen untuk ditelisik lebih jauh solusi konstruktifnya adalah: Bagaimana performa dan kapasitas UIN Alauddin Makassar pasca alih status dari IAIN?

Penelitian ini bertujuan untuk mendeskripsikan kapasitas dan capaian kinerja UIN Alauddin pasca alih suatu dan sebelumnya hanya fokus pada pengkajian dan pengembangan satu disiplim ilmu, tepatnya ilmu agama yang cenderung monolitik dan atomistik, menjadi lebih interdisipliner dan integratif dengan dibukanya fakultas-fakultas eksakta yang terintegrasi dan terkoneksi dengan disiplin ilmu agama dan keagamaan sebagaimana desain awalnya.

\section{Kerangka Konseptual}

\section{Pemetaan Kapasitas Pendidikan}

Secara leksikal, konsep pemetaan kapasitas, ditemukan dalam Business Dictionary, yang diartikulasikan sebagai, "analysis of an organization's structure and resources, aimed to identifying its inherent abilities and potential" (Pemetaaan kapasitas atau kapabilitas) merupakan analisis terkait struktur, sumberdaya, yang bertujuan untuk mengidentifikasi kemampuan dan potensi yang melekat di dalamnya (organisasi). It draws on a wide range of sources to develop (1) a definition of capacity building and (2) a conceptual framework for mapping capacity and measuring the effects of capacity building interventions. Melalui pemetaan kapasitas akan tergambar dengan jelas, kapasitas sumber daya yang dimiliki organisasi, termasuk satuan pendidikan sebagai organisasi pembelajaran, yang akan dikembangkan lebih lanjut. Juga memuat kerangka kerja konseptual pemetaan kapasitas dan pengukuran dampak dari intervensi kebijakan pengembangan kapasitas tersebut. Jadi, ketimbang hanya bergerak pada orientasi penguatan kompetensi pendidik, penguatan kapasitas sejatinya menyentuh aspek yang juga urgen, ketika kita membincang kapasitas organisasi pembelajaran, yang meniscayakan pengembangan lebih jauh.

Matachi, dalam laporannya Capacity Building Frameworks, UNESCO-IICBA 2006, mengartikulasikan konsep capacity is defined as the organizational and technical abilities,relationships and values that enable countries, organizations, groups, and individuals at any level of society to carry out functions and achieve their development objectives over time. Capacity refers not only to skills and knowledge but also to relationships, values and attitudes, and many others (emphasis added). Matachi meletakkan entitas seluruh sumber daya yang dimiliki, baik manusia, sarana dan prasarana, teknologi, intelektualitas, finansial, bersama dengan kemampuan aksesibilitas serta tata nilai sebagai kekuatan dasar untuk mengembangkan diri ke depan dalam menghadapi tantangannya yang semakin kompetitif.

Menempatkan konsep kapasitas dalam konteks pendidikan, maka, the term capacity in reference to the perceived abilities, skills, and expertise of school leaders, teachers, faculties, and staffs-most commonly when describing the "capacity" of an individual or school to execute 
or accomplish something specific, such as leading a school-improvement effort or teaching more effectively. The term may also encompass the quality of adaptation-the ability of a school or educator to grow, progress, or improve. Common variations include educator capacity, leadership capacity, school capacity, and teacher capacity, among others ${ }^{6}$.

Peter Brown dan Mary Cary, dalam proceeding hasil seminar tentang "Calculating School Capacity" (2007) memaknai capasitas sekolah sebagai, the number of students that can be reasonable accommodated by a school, building and size, dengan mempertimbangkan beberapa variabel yang inherent dalam proses pendidikan, meliputi: physical variables, operational variables, and programmatic variables. Peter Brown dan Mary Cary menguraikan secara komprehensif aspekaspek yang melekat dalam tiga variabel ketika membincang kapasitas insitusi pendidikan: a) physical variables, terdiri dari: 1) building size or area; 2) number/ types of teaching situation; 3) support facilities (luchroom, kichen, etc); 4) infrastructure; 5) net to gross ratio; 6) building and life-safety codes; 7) site amenities; b) Operational variables, terdiri dari: 1) utilization rates and efficiency; 2) operational policies; 3) staffing; 4) funding structure; 5) teacher and union regulations; 6) space management; 7) staff and operational budget; 8) specialty program offerings; dan c) Programmatic variables, meliputi: 1) class size and staff ratios; 2) educational program offerings; 3) operational models (teams, academics, etc); 4) specialty programs; 5) scheduls; 6) parthnership off-site learning, ect; 7) extended use.

\footnotetext{
${ }^{6}$ http://edglossary.org/diunduh, 14/08/2-16
}

\section{Kinerja Institusi Pendidikan Tinggi}

Ahuya (dalam Hilmi Muhammadiyah, 2016) ${ }^{7}$ dimana dijelaskan bahwa "perfomance is the way of job or task is done by an individual, a group of an organization" ( kinerja adalah cara perorangan atau kelompok dari suatu organisasi menyelesaikan suatu pekerjaan atau tugas). Stephen P. Robbins, kinerja merupakanhasilevaluasiterhadap pekerjaan yang telah dilakukan dibandingkan dengan kriteria yang telah ditetapkan bersama.

Pengukuran kinerja ini penting dilakukan bagi setiap organisasi, tak terkecuali organisasi pembelajaran seperti UIN, sebagaimana dikonstatasi Sterck, et. al.(2006) ${ }^{8}$, pengukuran kinerja merupakan penilaian melalui pengukuran dari kualitas ataupun kuantitas input, output, dan/atau outcomes dari suatu program atau organisasi dalam kaitannya dengan kepentingan masyarakat.

Dengan terpenuhinya kapasitas serta performa yang berkualitas, maka perguruan tinggi akan sampai pada tujuan da target capaian yang dirancang sedari awal, sebagaimama dikemukakan Diana Laurillard (2002) sebagaimana dirujuk Budi Widianarko (Kompas, 01/03/2014) berkenaan dengan tujuan perguruan tinggi, menyangkut pembelajaran (learning), terdiri dari: 1) menginspirasi dan memampukan individu-individu dalam mengembangkan kemampuan intelektualnya hingga ke

7 Hilmi Muhammadiyah, 2016. Review Hasil Pengawasan dan Audit Kinerja pada Balitbang Kemenag, disampaikan pada kegiatan Workshop RKAKL Balitbang Agama Makassar.

8 Sebagaimana dirujuk Penny Kusumastuti Lukito, 2014. Membumikan Transparansi dan Akuntabilitas Kinerja Sektor Publik, Jakarta: Gramedia, hal. 32 
tingkat yang paling tinggi; 2) memajukan pengetahuan dan pemahaman; 3) membentuk masyarakat demokratis dan beradab. Lendel (2010) bahwa dalam tren perekonomian berbasis ilmu pengetahuan (knowledge economic) universitas dapat dipandang layaknya sebuah industry, minimal dengan tujuh tawaran produk, yaiu pendidikan, produk budaya, tenaga kerja terampil, penelitian-kontrak, difusi teknologi, produksi pengetahuan baru, produk serta industry baru.

World Trade Organization (WTO) telah merilis empat jenis model penyediaan jasa pendidikan, ${ }^{9}$ terdiri dari: 1) cross border supply; 2) conumtion abroad; 3) commercial presence, and 4) presence of natural persons. Robinson dan Robinson (1995) $)^{10}$ mengelaborasi dengan mengemukakan bahwa keungulan kompetitif (competitive advantage) suatu organisasi menuntut pekerja berkinerja unggul, dan dampaknya adalah bahwa pendidikan, baik dalam tataran system serta kebijakan, khususnya dalam tataran organisasi kelembagaan perlu terus mencermati berbagai perubahan yang terjadi.

Setidaknya, jika mengacu pada WCU, QS, maupun The Times Higher Education, ada lima komponen yang semestinya dipenuhi penrguruan tinggi dalam upaya memberikan layanan prima, terumama jika berpretensi ingin kompetitif di tingkat glogal, sebagaimana dirilis www. pendis, kemenag. go.id (2014) $)^{11}$ diantaranya: akademik/pendidikan, reputasi di bidang penelitian, kerja sama internasional, rasio mahasiswa, dan dosen internasional, serta industry income.

\section{METODOLOGI PENELITIAN}

Artikel ini sebelumnya memanfaatkan tipologi penelitian kualitatif untuk mendeskruipsikan capaian kapasitas serta kinerja UIN Alauddin Makassar pasca alih status dari sebatas institut dengan segala keterbatasan yang melingkupinya. Informan yang menjadi sumber data primer ditetapkan dengan teknik purposeful sampling: terdiri dari: unsure pimpinan, dosen, tenaga administrasi dan tokoh pendidikan, baik yang masih aktif berkiprah di UIN Alauddin, maupun yang telah purna bakti, yangh sedari awal diasumsikan memiliki informasi berkenaan dengan topi kajian ini. Data tersebut digali melalui beberapa teknik, diantaranya wawancara mendalam (indepth interview), observasi dan studi dokumen. Kemudian, Data yang terkumpul melalui wawancara, observasi serta dokumen, dianalisis secara induktif-kualitatif, Miles dan Huberman (1999: 16) mengemukakan tiga alur yang biasa digunakan dalam analisis kualitatif, terdiri dari: reduksi data, penyajian data dan penarikan kesimpulan/ verifikasi.
9 Sebagaimana dirujuk Sofian Effendi (Koran Sindo, 13/03/2007)

${ }^{10}$ Uhar Suharsaputra, 2015. Majanemen Pendidikan Perguruan Tinggi: Strategi Menghadapi Perubahan, Bandung: PT Refika Aditama, hal. 2
11 Jejen Musfah, 2015. Manajemen Pendidikan: Teori, Kebijakan, dan Praktik, Jakarta: Prenada Media Utama, hlm. 290 


\section{HASIL DAN PEMBAHASAN}

\section{UIN Alauddin dalam Narasi Sejarah}

Sejarah perkembangan Universitas Islam Negeri Alauddin Makassar, yang dulu berstatus, tepatnya, Institut Agama Islam Negeri (IAIN) Alauddin Makassar melalui beberapa fase yaitu:

Era Transformasi menjadi Universitas Islam Negeri Alauddin. Fase ini merupakan domain paling penting dalam sejarah rihlah atau milestones ilmiah, ditandai dengan kesuksesan melakukan transformas besar (grand transformation) melalui proyek konversi atau alih status secara institusional, dengan wider manfate (kewenangan yang diperluas) menuju Uiniversitas Islam Negeri Alauddin, puncaknya pada era kepemipinan Azhar Arsyad, sebagai rektor pada masa khidmat 2002-2006. Status kelembagaan ini bertransformasi seiring dengan keluarnya Peraturan Presiden (Perpres) Republik Indonesia No 57 tahun 2005 tanggal 10 Oktober 2005 yang ditandai dengan peresmian penandatanganan prasasti oleh Presiden RI, kala itu dijabat Susilo Bambang Yudhoyono pada tanggal 4 Desember 2005 di Makassar.

Adapun basis kontekstual (illat) yang menjadi pijakan ikhtiar transformasi institusional ini, ${ }^{12}$ diantaranya:

Merebaknya ekspektasi publik terhadap institusi pendidikan tinggi Islam dalam upaya integrasi keilmuan, ilmu-ilmu agama dengan sains yang selama masih "keteteran", dengan status institut, IAIN hanya fokus pada kajian serta pengembangan satu disiplin ilmu saja

${ }^{12}$ Hadi Daeng Mapuna et.al (ed), 2015. Mengukir Sejarah Peradaban 50 Tahun IAIN/UIN Alauddin, Makassar: UIN Press, hal. 79-80 (monodisipliner), yaitu ilmu agama dengan membangun jarak dengan sains yang selama ini dituduh sebagai ilmu sekuler, sehingga kondisi ini menggiring isntitusi pendidikan ke dalam pusaran atomistik-dikotomis. Sehingga dengan wider mandate ini, maka diharapkan lulusan/sarjana yang diretas UIN adalah tipologi sarjana yang intelektual qum professional dalam keilmuan Islam yang tekoneksi dengan sains modern yang menjadi keniscayaan untuk berkompetisi di dunia global yang flat ini.

Semakin tingginya ekspektasi stakeholders dan shareholders akan penerapan pendidikan dengan materi multidisipliner yang ada pada program studi yang disiapkan. Institusi pendidikan, secara spesifik UIN sebagai provider, di dorong untuk mendeliver pengetahuan yang selaras dengan kebutuhan, khususnya demand pasar tenaga kerja.

Adanya fenomena yang berkenaan dengan semakin bertambahnya pengangguran intelektual dari tahun ke tahun,yang padagilirannya muncul berbagai sorotan public yang mempertanyakan kapasitas serta kinerja institusi perguruan tinggi di Tanah Air.

Adanya tuntutan dalam era reformasi yang member peluang otonomisasi yang lebih luas kepada Perguruan Tinggi sebagai lembaga pendidikan dan pengkaderan pemimpin-pemimpin bangsa di masa depan. Bagi UIN Alauddin sendiri, realitas ini menjadi pijakan dalam melakukan langkah-langkah kongret dan progresif ke arah pengembangan dan peningkatan pelaksanaan Tirdarma Perguruan Tinggi yang sejalan dengan "roh" reformasi itu sendiri, yaitu pengelolaan perguruan 
tinggi dengan system manajemen yang professional, transparan, mandiri dan demokratis.

Dalam perubahan status kelembagaan dari Institut ke Universitas , UIN Alauddin Makasar mengalami perkembangan dari lima (5) buah Fakutas menjadi 7 (tujuh) buah Fakultas dan 1 (satu) buah Program Pascasarjana (PPs) berdasarkan Peraturan Menteri Agama RI Nomor 5 tahun 2006 tanggal 16 Maret 2006, dan saat ini 2016 telah bertambah menjadi 8 Fakultas dan I Program Pascasarjana, sebagai berikut:13 ${ }^{13}$ Fakuktas Syari'ah dan Hukum, Fakuktas Tarbiyah dan Keguruan, Fakultas Ushuluddin dan Filsafat, Fakultas Adab dan Humaniora, Fakultas Dakwah dan Komunikasi, Fakultas Sains dan Teknologi, Fakultas Ekonomi dan Bisnis Islam, Fakultas Kedokteran Ilmu Kesehatan dan Prgoram Pascasarjana(PPs).

\section{Kapasitas UIN Alauddin}

Mengacu pada makna konsep kapasitas, dan variabel-variabel yang inheren di dalamnya, sebagaimana didekripsikan sebelumnya, maka pada bagian ini diartikulasikan beberapa aspek berkenaan dengan kapasitas yang saat ini ada di UIN Alauddin Makassar, sebagai keniscayaan yang sejatinya dipenuhi perguruan tinggi yang berikhtiar untuk leading di masa depan, di tengah ketatnya persaingan antar perguruan tinggi, baik di tingkat regional, maupun global. Capacity sebagaimana dimaknai Matachi (2006) refers not only to skills and knowledge but also to relationships, values and attitudes, and many others (emphasis added). Bertolak dari proposisi Matachi ini, pemetaan

\footnotetext{
${ }^{13}$ Ibid, hlm. 81
}

kapasitas dan performa UIN Alauddin menjadi penting sebagai acuan dalam perumusan dan selanjutnya pengambilan kebijakan (decision making) terkait tata kelola secara kepemimpinan, kualitas lulusan, kualitas infrastruktur, riset dan pengajaran yang sejatinya ditingkatkan secara terusmenerus. Tepat di titik ini, ada benarnya klaim salah seorang informan (AB/55 Tahun), dalam konteks kekinian, menjadi keniscayaan untuk megimplementasikan prinsip Good University Governance untuk meningkatkan tata kelola. Ada 4 aspek yang dititikberatkan, pada domain leadership Perguruan Tinggi Keagaman Islam Negeri, pembelajaran (learning), dan yang juga sangat urgen adalah sember daya pada line up supporting staf.

Komponen ini sebagaimana dikutip Suparlan (2013), ${ }^{14}$ yang kemudian dimasukkan sebagai bagian dari komponen sistem pendidikan nasional, dengan berpijak pada teori sistem produksi, yang lebih popular dengan komponen input instrumental yang terdiri dari: sumberdaya manusia dan infrastruktur dan kurikulum.

Mimpi yang ingin direngkuh UIN Alauddin terpahat dalam visi yang ingin "dibumikan". Secara institusional kemampuan untuk mengembangkan institusi berupa refleksi berkenaan dengan nilai-nilai, budaya, keyakinan, mata pamong, visi dan misi, serta orientasi pengembangan merupakan keniscayaan. Mengingat orientasi strategis yang dipandu oleh visi bersama pihak universitas, yang sarat dengan nilai-nilai yang dirawat bersama dan

${ }^{14}$ Suparlan, 2013. Manajemen Berbasis Sekolah dari Teori sampai dengan Praktik, Jakarta: Bumi Aksara, hlm. 21 
menjelaskan arah institusi atau organisasi untuk menjemput masa depan, serta dijdikan sebagai arahan dan tujuan pihak manajemen, adapan goresan visi tersebut adalah (ingin) menjadi pusat keungulan akhlak dan akademik, pelopor peradaban Islam di Kawasan Timur Indonesia serta lembaga pendidikan tinggi terkemuka (centre of excellence) yang mengintegrasikan keagungan akhlak, keluasan ilmu, keislaman, kemoderenan dan peradaban. Maka, tak ayal jika kemudian kampus UIN kini lebih familiar dengan istilah "kampus peradaban."

Visi tersebut kemudian di-breakdown ke dalambeberapa misi yang diklaim Tony Bush, et.all, kerap digunaan untuk menjelaskan seluruh tujuan dan filosofi (organisasi), secara spesifik memanifestasikan nilainilai institusi. Seidaknya, terdapat 6 poin yang dirumuskan UIN Alauiddin dalam mengejawantahkan visi diatas, yaitu: 1) melakukan interkoneksitas dan reintegrasi epistemology keilmuan, sehingga tidak ada lagi dikotomi antara ilmu-ilmu umum dan ilmu-ilmu agama; 2) memberikan landasan moral terhadap pengembangan IPTEK dan melakukan pencerahan dalam pembinaan IMTAQ, sehingga IPTEK dan IMTAQ dapat sejalan; 3) mempertahankan nilai-nilai lama yang positif dan mengambil nilai-nilai baru yang lebih positif; 4) mengembangkan pendidikan, penelitian, dan memberikan kontribusi terhadap peningkatan kualitas hidup melalui pola pengabdian masyarakat yang lebih professional; 5) memberikan kontribusi dalam mewujudkan perdamaian dunia dan kesejahteraan umat manusia; dan 6) menjadi faktor yang menentukan dalam memelihara hubungan harmonis intern umat beragama, antara umat beragama dan hubungan antara penganut agama dan pemerintah.

Namun, seiring dengan suksesi kepemimpinan, secara berkelindang visi dan misi itupun berubah, terbukti sejak era kepeimpinan Abd Qadir Gassing menjadi nakhoda, ia pun merevisi visi yang sebelumnya telah dirumuskan, adapun visi tersebut tergurat sebagai berikut:"Pusat pencerahan dan Ipteks Berbasis peradaban Islam: Kecepatan perubahan visi UIN ini menandakan bahwa visi sebagai proyeksi serta gambaran masa depan yang ingin direngkuh UIN Alauddin, di dalamnya juga inheren deskripsiterkait proses transformasi serta perubahan yang dicita-citakan dengan berpijak pada capaian di masa depan tersebut, tidak dikaji lebih holistic dan komprehensif, sehingga patologi birokrasi yang selama ini endemik bahwa, pergantian pemimpin suatu organisasi secara berkelidang akan mengikuti pengerusan visi, misi dan kebijakan strategis yang telah dipahat sebelumnya. Hal ini menyitarkan, bahwa visi serta misi yang dirumuskan cenderung elitis, hanya melibatkan beberapa orang saja, tanpa melibatkan seluruh stakeholder institusi tersebut, baik publik di internal organisasi maupun publik eksternal yang menjadi pengguna utama layanan pendidikan perguruan tinggi seperti UIN Alauddin Makassar, sebagaimana dikemukakan A. Hanif (2008: 5), ${ }^{15}$ bahwa, kelangsungan hidup perguruan tinggi, tidak lepas dari masyarakat sebagai pengguna. Lebih jauh, Mastuhu mengelaborasi penting semua kalangan yang terlibat harus

15 A. Hanif Saha Ghafur, 2008. Manajemen Penjaminan Mutu Perguruan Tinggi di Indonesia, cet. I, Jakarta: Bumi Aksara, hlm. 5 
memiliki visi yang jauh ke depan berkenaan dengan pengembangan perguruan tinggi Islam (Mastuhu, 1999: 84).

\section{Karakteristik UIN Alauddin}

Karakteristik atau ciri pembeda yang ingin diretas UIN Alauddin adalah bahwa, kajiannya selain mendasarkan kebenaran pada hasil-hasil observasi dan eksperimen dalam kerangka pengembangan budaya saintifik juga melihat pesan-pesan dari Kitab Suci Alquran dan Sunnah. Oleh karena itu, para mahasiswa selain dituntut menguasai bahasa Indonesia dan Inggris, juga menguasai bahasa Arab merupakan suatu keniscayaan juga, sebagai piranti memahami kitab suci, sunnah dan manuskrip klasik. Kajian Islam dianggap sebagai ciri oleh karena intensitas dilakukan secara mendalam dan tidak sebatas sebagaimana dilakukan oleh universitas pada umumnya.

Sasaran yang ingin direngkuh oleh UIN Alauddin adalah melahirkan lulusan yang memiliki: 1) kekokohan akidah; 2) kedalaman spiritual; 3) keunggulan akhlak; 4) keluasan ilmu; dan 5) kematangan profesionalitas. Oleh karena itu, agama dipandang sebagai doktrin yang harus terejawantah dalam kehidupan sehari-hari. Maka, kampus Universitas Islam Negeri selain menyediakan laboratorium, ruang kuliah, perpustakaan, juga menyiapkan masjid dan ma'had mahasiswa. Masjid dan ma'had dijadikan sebagai wadah dalam membentuk watak dan kultur kehidupan beragama.

"UIN sedang dipersiapkan untuk memproduksi ulama unggul yang tak hanya menguasai ilmu-ilmu keislaman melainkan juga sains dan teknologi. Ulama yang tak hanya mengerti soal-soal fikih yang bertumpu pada al-Qur'an dan hadits tetapi juga menguasai teori-teori sains yang berbasis pada kerangka etik agama." Di tangan ulama yang demikian itulah, corak peradaban di Nusantara akan ditentukan," tambahnya" perubahan IAIN ke UIN menjadi kehendak dan tuntutan zaman bahwa IAIN harus mulai melebarkan mandat akademisnya. Jika IAIN hanya berorientasi pada pengembangan ilmu-ilmu keislaman tradisional, maka lebih dari itu, UIN harus dapat berperan dalam pengembangan sains dan teknologi (Lukman Hakim Saifuddin, Pinmas, 08/04/2016).

Dari sisi orientasi pengembangan kajian setelah melalui proses wider mandate, UIN ke depan menurut Azhar Arsyad dalam upaya merumuskan arah pengembangan kajian keilmuan di UIN Alauddin, diharapkan juga UIN mengembangkan bidang-bidang kajian yang bersifat spesifik, selain memiliki ciri universal seperti yang ditempuh UIN lainnya. Dalam bidang kajian spesifik ini, diharapkan isu-isu yang spesifik eksis di Kawasan Timur Indonesia akan menjadi concern utama. Kajian bisa dimulai, misalnya, melalui penelitian-penelitian terhadap sejarah kepurbakalaan, dan naskah-naskah kuno di Sulawesi Selatan hingga Papua.

Karakteristik (branding) UIN Alauddin juga ditemukan pada aspek epistemolog kelimuan yang ingin dikembangkan. Hal ini berangkat dari kesadaran civitas akademik bahwa, tranformasi institusional IAIN menjadi UIN beriringan dengan tuntutan berkenaan dengan ikhtiar pengembangan secara berkelanjutan, terutama pada beberapa domain sebagai program prioritas, meliputi:1) peningkatan kapasitas akademik; 2) peningkatan tata kelola, pamong dan 
institusi; 3) peningkatan kapasitas sumber daya manusia; dan 4) peningkatan kapasitas infrastruktur.

\section{Kapasitas SDM dan Infrastruktur}

Human capital-pendidik dan tenaga kependidikan-dalam sebuah organisasi, tak terkecuali leaning organization seperti UIN merupakan komponen yang sangat penting, dan menentukan kapasitas serta perfirma UIN kini dan ke depan, baik pada domain pembelajaran, penelitian maupun pengkhidmatan kepada masyarakat. Dan di titik inilah yang menjadi pembeda antara institusi pendidikan dengan organisasi lainnya, sebagaimana yang diafirmasi Sergiovanni, et.al (1987), "16 "school are human organization in the sence that their products are human and their processes require the socializing of human."

Urgensi dosen dan tenaga kependidikan ini disadari betul oleh kalangan civitas akademik UIN, hal ini terejawantah pada konstatasi informan (ML/58 Tahun), ${ }^{17}$ kualitas human capital ini merupakan indikator/penentu utama, baik secara kuantitatif maupun kualitatif dalam upaya mengakselerasi peningkatan kualitas serta performa organisasi seperti UIN ini. Sehingga aspek ini menjadi skala prioritas untuk dipacu di tengah tuntutan agar UIN bisa mencapai keunggulan komparatif maupun kompetitif ke depan.

Kapasitas yang telah dicapai UIN Alauddin berkenaan dengan kualitas sumberdaya manusia saat penelitian ini

${ }^{16}$ Uhar Suharsaputra, 2015. Majanemen Pendidikan Perguruan Tinggi: Strategi Menghadapi Perubahan, Bandung: PT Refika Aditama, hal. 137

${ }^{17}$ Interview di Makassar, 10/02/2016 dilakukan berjumlah 536 orang dengan kualifikasi doktor sebanyak 99 orang dan 35 guru besar yang tersebar di 46 program studi (Hasil Penelitian Puslitbang Penda, Balitbang Kemenag RI, 2014). Kalangan pendidik ini merupakan "jebolan" beberapa perguruan tinggi ternama, baik dalam maupun luar negeri. Terdapat beberapa Negara yang selama menjadi Negara tujuan pendidik UIN melakukan rihlah ilmiah, diantaranya: Amerika Serikat, Jerman, Belanda, Kanada, Australia, Mesir, Pakistan, Sudan, Filipina, dan Malaysia. Selang beberapa tahun kemudian, tepatnya berdasarkan hasil pendataan EMIS tahun 2015/2016 (semester ganjil, jumlah dosen UIN Alauddin telah mencapai 703 orangyang bisa diklasifikasikan berdasarkan kualifikasi pendidikan, sebagai berikut: S3 sebanyak 200 orang; S2 495 orang dan kualifikasi S1 sebanyak 8 orang dengan membina mahasiswa sebanyak 23. 576 orang (Emis, 2015/2016). Selain donsen domestic, di UIN juga kerap mendapatkan bantuan penaga pengajar dari beberapa Negara, seperti Mesir, Arab Saudi dam Amerika Serikat.

Jika dideskripsikan profil institusi pendidikan ini sebelum bertransformasi menjadi UIN, maka akan tampak pada capaian program pengembangan kerenagaan yang sedari awal diproyeksikan untuk peningkatan kualitas, kuantitas serta efektifitas ketenagaan ini. Program ini meliputi:

Penambahan jumlah tenaga pengajar, pustakawan, peneliti, tenaga computer dan mutu serta efisiensi, dengan prokyesi lima tahun ke depan rasio antara dosen dengan mahasiswa berada dinisbah $1: 20$, rekritmen peneliti secara signifikan, minimal 10 orang; rekruitmen tenaga pustakawan, rekruitmen 
tenaga teknisi computer 10 orang dan tenaga administrasi yang sesuai formasi.

Peningkatan kualitas pendidik dan tenaga kependidikan melalui pendidikan dan latihan, di dalam maupun di luar negeri, terdiri dari: 1) pascasarjana strata dua (S2) yang sebelumnya berjumlah 17 orang ditingkatkan menjadi 52 orang; 2) pascasarjana setingkat strata tiga (S3) ditingkatkan menjadi 24 orang; 3) pembibitan tenaga pendidik aggregat 21 orang di tahun pertama; 4) pelatihan bagi kalangan peneliti sebanyak 64 orang; pustakawan 21 orang; dan tenaga teknisi computer 10 orang serta pendidikan bahasa Inggris sebanyak 15 orang.

Profil mutu pendidik, saat ini meliputi: 1) aggregate pendidik menurut golongan, sebanyak 536 pendidik tetap dengan rincian sebagai berikut: 1) Lektor ke atas aggregate . 11, 3 persen; Lektor Madya ke bawah dengan aggregate 88, 67 persen. Mutu pendidik ini sudah dalam perencanaan untuk ditingkatkan kapasitasnya lima tahun ke depan, dengan proyeksi Lektor ke atas 20 persen, sementara Lektor Madya ke atas sebanyak 80 persen.

Konfigulasi jenjang pendidikan tenaga edukatif permanen S1, S2 dan S3, dengan kondisi sekarang tampak masih sangat timpang, dengan rasio 388: 27: 9, jika dikonversi menjadi 45: 3: 1. Rencana pengembangan ke depan dalam interval lima tahun ke depan diupayakan rasionya akan bergeser secara signifikan, yakni 15: 6:3

Di samping itu, forecasting berkenaan dengan kualifikasi jenjang kepangkatan jabatan akademik antara Guru Besar, Lektor dan Asisten dengan kondisi sekarang berada di rasio 32: 68. Dan telah didesain pengembangannnya, menjadi kualifikasi 2 : 4: 8 .

Rasio antara tenaga edukatif dengan mahasiswa pun demikian, kapasitas sumber daya manusia yang memuliki tugas dan fungsi pada tridarma, dalam hal ini dosen yang secara kumulatif berjumlah 536 orang dengan aggregate mahasiswa yang dibina menyentuh angka 17. 618 orang dengan rasio $1: 32$, dan telah diproyeksikan pengembangannya lima tahun ke depan menjadi $1: 20$ orang.

Selain sumberdaya manusia yang sejatinya melekat dalam organisasi pembelajran, yang juga penting disiapkan adalah komponen prasarana serta sarana atau infrastruktur pendukung. Membincang mengenai ketersedian infrastruktur pendidikan yang kini dimiliki UIN, tergolong sudah sangat maju, perguruan tinggi ini memiliki dua kampus; kampus satu yang berada di kota Makassar, kampus ini berada di lahan seluas $60.439 \mathrm{~m}$ persegi yang selama ini menjadi pusat manajemen dan perkuliahan yang terdiri dari 5 fakultas dan gedung rektorat, kondisi ini tidak terlalu kondusif lagi sebagai lingkungan akademik, sebab selain lingkungan sudah sesak dan sempit dengan fasilitas yang sudah mendekati using, sehingga kerapkali menimbulkan ketidaknyamanan dalam aktivitas proses belajar mengajar dan kegiatan akademik lainnya. Seiring dengan perkembangan status kelembagaan, dan kota Makassar pun semakin padat dan bising, maka sejak tahun 1994 mulai dikembangkan kampus II yang berada di Kabupaten Gowa dengan luas lahan $363.286 \mathrm{~m}$ persegi. Jarak antara kampus I dengan kampus II sekitar 9 kilometer, pembagunan kampus 
II sepenuhnya menggunakan dana bantuan dari IDB (Islamic Development Bank).

Lanskap kampus II pun berbeda jauh dari kondisi lingkungan kampus I yang mulai tampak kumuh, Penataan Kampus II memang menjadi target Azhar Arsyad sebelum menyerahkan estafet kepemimpinan pada rector berikutnya, sebagaimana ia janjikan, ia ingin agar penampilan luar kampus II UIN, baik dari penataan gedung, koridor, gazebo, taman, pagar, dan gapura. Kita ingin mewujudkan kampus UIN Alauddin sebagai kampus yang indah dan bersih, menyejukkah sehingga siapapu yang memasuki kampus ini akan merasa betah dan hendak tinggal berlama-lama di dalamnya.

Praktis sejak bertransformasi menjadi UIN, perguruan tinggi Islan negeri terbesar di Kawasan Timur Indonesia ini berhasil mendapatkan bantuan dana dari IDB (Islamic Development Bank). Bantuan IDB ini dialokasikan untuk pembangunan infrastruktur terutama pembangunan gedung/sarana perkuliahan dan perkantoran, sehingga kini proses perkuliahan dan perkantoran lebih terkonsenrtrasi di Kampus II dengan fasilitas yang sangat lengkap dan kompetitif; Rektorat, Lecture Theatre, Pusat kegiatan Mahasiswa (PKM), dilengkapi dengan sarana dan prasarana modern. Sementara di kampus I saat ini, masih sifanyta dalam proses rehabilitasi, juga telah berdiri megah dia gedung tujuh lantai, yang diperuntukkan sebagai Training Centre, sebagai pusat Badan Layanan Umum (BLU) yang sifatnya multifungsi dengan fasilitas hotel bintang empat sehingga kerap pula disebut Hotel Alauddin, dan beberapa ruangan kerap digunakan perhelatan seminar, workshop, meeting dan resepsi pernikahan, sehingga secara actual manfaat dari segala fasilitas ini tidak hanya focus untuk kepentingan civitas akademika UIN, melainkan lebih luas dari itu, untuk kepentingan public secara makro. Di sisi kiri hotel Alauddin pun kini berdiri magah perpustakaan tiga lantai yang juga sedang dalam penataan. Tepat di bagian depannya pun kini berdiri megah nan kokoh bangunan lebih dari 10 lantai yang diperuntukkan untuk rumah sakit pendidikan Fakultas Kedokteran dan ilmu Kesehatan UIN Alauddin yang sudah dalan tahap finalisasi.

Akselerasi pembangunan infrastruktur pasca transformasi secara institusional perguruan tinggi merupakan keniscayaan dimana there is no point to return, sebagai konsekwensi logis ikhtiar pengembangan yang meminjam istilah Mastuki-sebagai "lompatan quantum" ini. Terutama didorong oleh kebutuhan untuk menampung calon mahasiswa yang mulai membludak setelah berubah menjadi UIN, salah seorang informan membandingkan, bahwa pada saat masih berstatus IAIN aggregat mahasiswa yang dibina masih diangka 3000 orang. Namun, setelah beralih status menjadi UIN melonjak tinggi sampai mencapai angka 25 ribu orang. Dan, tidak berhenti sampai di angka itu, sebab ternyata dari tahun ke tahun selalu mengalami kenaikan, misalnya di 2014 saja, jumlah peminat yang mendaftar di UIN mencapai angka 67 ribu orang (ML/58 Tahun).

\section{Akreditasi Institusi dan Program Studi}

Akreditasi dapat dikategorikan sebagai bagian dari indikator akuntabilitas institusi pendidikan terhadap publik dan/atau konsumen. Meskipun, dari jauh Perre 
Bourdieu $^{18}$ menyoroti pola assessmen ini dengan nada satir, bahwa sekolah maupun institusi pendidikan terakreditasi lainnya adalah milik kelas atas. Sebab, bagi dia, dalam masyarakat modern institusi pendidikan merupakan lembaga yang melakukan reproduksi sosial. Tapi, untuk konteks Indonesia-meskipun sedikit kedengaran rasionalisasi-akreditasi merupakan rangkaian penilaian yang berorientasi pada kinerja atau capaian yang telah direngkuh sebuah organisasi, tak terkecuali organisasi pembelajar seperti UIN Alauddin, meminjam istilah Baedhowi-result driven (Media Indonesia, 12/03/2016). Asesmen seperti ini pebih menekankan pada hasil yang dicapai dari sebuah rangkaian penilaian dengan mengacu kepada standar yang telah ditetapkan sebagai benchmarking utama dalam kerangka penilaian capaian kualitas dan juga positioning UIN Alauddin dalam konfigurasi perguruan tinggi di Tanah Air. Akreditas institusi memanifestasikan kondisi aktual dan obyektif kapasitas universitas di aras lokal, sederhananya, lebih riil di lapangan.

Dan akreditasi sebagai indikator penjaminan mutu (qualityinsurrence) institusi maupun program studi menjaditarget utama yang digapai Rektor UIN periode masa bakti 2015-2019, Musafir Papabari dan jajarannya. Dengan kesadaran bahwa, kini perguruan tinggi merupakan keniscayan untuk selalu memastikan semua program studi yang

${ }^{18}$ Sebagaimana dirujuk Nanang Martono, 2017. Sekolah Publikvs Sekolah Privat dalam Wacana kekuasaan, Demokrasi, dan Liberalisasi Pendidikan, Jakarta: Obor Indonesia, hlm 19, atau bisa dilihat kembali ke Piree Bourdieu, 1993. The Field of Cultural Production, diterj. Yudi Santoso: Arena Produksi Kultural: Sebuah Kajian Sosiologi Budaya, Bantul: Kreasi Wacana mereka kelola, terakreditasi. Kewajiban akreditasi juga diarahkan agar diperluas kepada institusi Perguruan Tinggi, tepatnya akreditasi secara institusional. Sebab, jika perkara akreditasi tidak dituntaskan, maka akan berdampak buruk pada lulusan yang akan mencari pekerjaan, dimana kerap perkara akreditasi yang menjadi patokan untuk menilai kompetensi tenaga kerja saat ini. ${ }^{19}$ Dan, dampaknya tidak hanya sampai di situ, tapi lebih luas ke domain publik, yang nantinya masyarakat yang menilai juga akan pikir-pikir daftarkan putra-putri mereka, kalau akreditasi rendah. Untuk itu, kami ada sistem penjaminan mutu internal, sehingga proses penjaminan terlaksana.

Dari dan sekitar 20 ribuan program studi yang tersebar di seluruh perguruan tingginegeri maupun swasta-, Dari sisi institusi UIN Alauddin per 2017 mendapatkan status akreditasi B, Saat ini kita masih di bawah peringkat 100 karena memang akreditasi kita masih B meski demikian kita targetkan akreditasi A tahun 2019 dan saya optimis bisa," kata Prof Musafir (tribuntimur. com, diunduh 10/09/2017). Tercatat beberapa prodi yang ada di UIN yang telah terakreditas, baik akreditas A, B, maupun status akreditasi $\mathrm{C}$.

Capaian mutu melalui indikator akreditasi institusi maupun program studi

${ }^{19}$ Sebagai perbandingan-dan ini penting untuk dijadikan bahan refleksi pengambil kebijakan berkenaan dengan quality assurance di UIN AlauddinACDP merilis data Daerah-daerah-di luar Jawa- malah belum punya perguruan tinggi dengan akreditasi A, baik negeri maupun swasta. Akibatnya, banyak lulusan yang mengangggur. Data ACDP Indonesia menyebutkan, 40 persen lulusan perguruan tinggi di Papua kini menganggur. Sedangkan di Nusa Tenggara dan Kalimantan, sebanyak 20 persen lulusan dari program studi tertentu, masih menganggur (ACDP, diunduh 09/03/2017) 
di atas, tampak mengalami peningkatan mutu secara akseleratif, jika dibandingkan dengan riset yang dilakukan beberapa tahun sebelumhya, tepatnya di tahun 2013, kala itu ditemukan program studi-program studi yang ada di UIN Alauddin masih didominasi akreditasi $C$ dengan aggregate 25 program studi (54 persen), program studi yang berakreditasi B sebanyak 20 (43,5 persen), dan yang merengkuh capaian akreditasi A hanya satu program studi (2,2 persen).

Di tengah segala keterbatasan BAN-PT untuk melakukan kegiatan akreditasi yang hanya mampu mengakreditasi sekitar 4000 ribuan per tahun, Setiap tahun, 1.000-2.000 program studi (prodi) yang tersisa tidak diakreditasi BAN-PT karena keterbatasan anggaran dan assesor. ${ }^{20}$ Adapun prodi-prodi yang telah terakreditas dengan capaian masing-masing fakultas yang ada di UIN saat ini, yaitu prodi yang terakreditasi A terdiri dari program studi bahasa dan sastra Arab; manajemen dakwah; sejarah dan kebudayaan Islam, dan ekonomi syariah.

20 Sebanyak 4.110 atau 96 persen dari total perguruan tinggi di Indonesia belum terakreditasi. Padahal, akreditasi merupakan salah satu ukuran yang dapat digunakan untuk menilai kualitas suatu kampus. Dari 4.300 lebih perguruan tinggi di Indonesia, hanya 26 yang akreditasinya sudah A. "Yang akreditasi A ada 26, B ada 69, dan C (ada) 74. Perguruan tinggi terakreditasi sebanyak 169, dan yang belum punya akreditasi 4.110," (www. korankaltim. com, diunduh, 01/08/2016). Lagi-lagi ini terkendala oleh terbatasnya alokasi anggaran dalam APBN untuk program akreditasi, Ketua Badan Akreditasi Nasional Perguruan Tinggi (BAN-PT) Mansur Ramli mengatakan, BAN-PT membutuhkan biaya Rp 30 juta-Rp 35 juta untuk setiap program studi (prodi), dan untuk akreditasi institusi atau perguruan tinggi membutuhkan hingga Rp 50 juta per institusi. Anggaran saat ini hanya cukup untuk 5.000 prodi, sedangkan rata-rata ada 7.000 prodi tiap tahunnya.
Sementara tercatat sudah 32 prodi yang bertengger di akreditasi B sebagai berikut: program studi akuntansi; biologi; bimbingan dan penyuluhan Islam; akidah dan filsafat; ekonomi Islam; farmasi; filsafat agama; hukum acara peradilan dan kekeluargaan; hukum pidana dan ketatanegaraan; ilmu alquran dan tafsir; ilmu ekonomi; ilmu hadis; ilmu hukum; ilmu komunikasi; ilmu politik; ilmu perpustakaan; jurnalistik; kesehatan masyarakat; komunikasi dan penyiaran Islam; manajemen; manajemen dan pendidikan Islam; pendidikan agama Islam; pendidikan bahasa Arab; pendidikan fisika; pendidikan matematika; pengembangan masyarakat Islam; perbandingan agama; perbandingan mazhab dan hukum; sosiologi agama; teknik perencanan wilayah dan kota; pendidikan bahasa Arab dan prodi tafsirhadis. Dan, prodi-prodi yang merengkuh akreditas C, terdiri dari prodi kebidanan; profesi Ners; bahasa dan sastra Inggris; fisika; ilmu aqidah; ilmu peternakan; keperawatan; kimia; matematika; pemikiran politik Islam; pendidikan bahasa Inggris; pendidikan biologi; pendidikan guru madrasah ibtidaiyah; sistem informasi; teknik arsitektur; dan terknik informatika.

Hasil akreditasi ini mengejawantahkan bahwa, kapasitas lecturing pada institusi telah mengalami perkembangan yang cukup menggembirakan. Meskipun demikian, hasil inilembagatersebut masih menyisakan tugas berat dalam hal tata kelola di ranah lecturing. Sambil tetap berkomitmen untuk memenuhi aspek kelengkapan dan ketertiban data yang dimiliki oleh organisasi untuk semua proses manajemen internalnya.

Setelah beberapa tahun berjalan, akhirnya izin membuka program studi (prodi) kedokteran diberikan kepada UIN 
Alauddin Makassar, pihak UIN lalu diminta komiten untuk tetap mengurusi dan melengkapi berbagai persyaratan, antara lain dosen, laboratorium, dan rumah sakit pendidikan dalam satu tahun ke depan agar tetap menjaga kualitas pendidikan.

\section{Kebijakan terkait Jaminan Mutu}

Bepijak pada delapan prinsip manajemen mutu yang menjadi indikator ISO. 9001:2000 yang dijadikan pijakan UIN dalam mendesain arah perkembangan kualitasnya ke depan, meliputi: fokus pada penerima layanan; kepemimpinan; pelibatan segenap personil; pendekatan proses; keputusan berdasarkan sistem; penyempurnaan berkelanjutan; pendekatan fakta; dan hubungan penyuplai yang saling mengutungkan.

Sebagai lembaga pendidikan tinggi yang sedang menuju upaya pencapaian kualitas, baik dari sisi keunggulan komparatif maupun keunggulan kompetitif, UIN Alauddin Makassar mampu mengembangkan integrasi Islam, sains, teknologi, dan seni serta menghasilkan lulusan berdaya saing tinggi, berakhlak mulia dan berperadaban. Adapun sasaran mutu yang ingin dicapai ke depan, meliputi: 1) Karya penelitian tentang integrasi Islam,sains, teknologi dan seni minimal 50\%; 2) Karya ilmiah staf edukatif yang dipublikasikan internasional minimal 10 buah pertahun; 3) Lulusan berkarya di masyarakat sesuai bidang keahlian dalam tahun pertama minimal 50\%; 4) Tepat waktu studi minimal $80 \%$; 5) Indeks Kinerja Dosen > 3.0 minimal 60\%; 6) Lulusan mampu berkomunikasi global (TOEFL's Score minimal 450 dan TOAFL's Score minimal 65 skala 100); 7) Lulusan mampu mengaplikasikan teknologi informasi minimal $80 \%$.

Dalam kerangka pencapaian mutu di atas, maka pihak civitas akademik telah mendesain enam program unggulan yang dalam proses pembenahan sebagian bagian dari kebijakan arah pengembangan secara makro, meliputi: 1) Inner Capacity Building (Pembinaan Kapasitas dan potensi sisi dalam diri manusia); 2) Intellectual and Academic Capacity Building (Pembinaan Kapasitas Intelektual dan Akademik); 3) Keagungan akhlaq, kedalaman spritual, kekokohan akidah, keluasan ilmu, dan kematangan profesionalisme; 4) Institutional Capacity Building(PembinaanKapasitasInstitusional); 5) Social Capacity Building (Pembinaan Kapasitas Sosial); dan 6) Entrepreneurship and Managerial Capacity Building (Pembinaan Kapasitas Kewirausahaan dan Manajerial)

Dan, dari sisi proyek pengembangan, UIN Alauddin telah mendesain dan menyasar lima belas aspek/domain dalam kerangka peningkatan mutu, terdiri dari: kepemimpinan; kemahasiswaan; sumber daya manusia; kurikulum; prasarana dan sarana; pembiayaan; tata pamong (govermance); sistem pengelolaan; sistem pembelajaran; budaya akademik; sistem informasi; sistem jaminan mutu internal; kualitas lulusan; penelitian serta pengabdian masyarakat; dan program studi.

\section{Program Seribu Buku}

Di tengah proses pembelajaran yang selama ini berjalan di UIN, muncul terobosan yang diklaim sangat monumental di kalangan civitas akademika UIN, yaitu upaya untuk menghadirkan produk-produk pengembangan keilmuan, baik dalam 
bentuk hasil riset pustaka, kajian lapangan, maupun buku-buku daras, yang berbasis pada program seribu buku. Gagasan ini tergolong inovatif di tengah melambatnya kegiatan riset dan publikasi selama ini, hal ini dibuktikan melalui bahwa hingga tahun 2014, tercatat hasil-hasil riset yang dipublikasikan sekaligus ber-ISSN hanya menyentuh angka 76 buah; artikel yang diterbitkan dalam jurnal internasional baru 1 artikel; artikel dosen yang terbit di jurnal terakreditasi nasional sebanyak 12; artikel yang terbit di jurnal kampus sebanyak 56; hasil riset yang di-upload; dan belum ada satu pun hasil riset yang patenkan.

Namun, perlu dicatat bahwa sampel yang terpilih pada waktu penelitian ini dilakukan, hanya 10 program studi dari aggregate prodi yang eksis di UIN ketika itu. Sehingga, terang saja, terobosan seribu buku ini diklaim sebagai "oase" di tengah lesunya-untuk tidak menyatakan bekunyasemangat menulis buku sebagai genre karya ilmiah di kalangan dosen UIN Alauddin. Sang rector, yang kala ini dijabar Qadirt Gassing mencairkan kebekuan tersebut melalui gerakan penulisan buku secara massif. Hal ini menjadi penanda bahwa, selang hanya satu dasawarsa pasca konversi institusional, UIN telah mampu meretas program inovatis dari sisi output penelitian,

Kembali membincang program seribu buku, yang diretas pada era kepemimpinan Abd Qadir Gassing ini, menuai apresiasi yang sangat luas. Sebagai pimpinan, kemampuan untuk memberdayakan hasil intelektual perguruan tinggi yang dikelolanya, sehingga benefitnya bermanfaat bagi kalangan stakeholders, diantaranya publik, dunia industri, dunia usaha, dan juga pemerintah. Gerakan seribu buku ini menurut informan telah menjadi momen pembuktian civitas akademik UIN bahwa selama ini human capital yang dimiliki UIN sarat dengan inner capacity, yang jika dirangsan (trigger), inipun sekaligus membuktikan bahwa kalangan intelektual yang selama ini ditengarai berada di menara gading hanya concern dengan satu aspek tridarma perguruan tinggi, yaitu mengajar semata, akhirnya mulai melalakukan diversifikasi program yang sejatinya sejak dulu mereka lakukan. Dan, muaranya, kerja keras ini mendapatkan apresiasi dari berbagai kalangan, dan yang paling membanggakan adalah penghargaan dari MURI dengan rekor sebagai penghasil buku ilmiah terbanyak, hingga kini rekor itupun tak terpecahkan.

Kesempatan penulisan seribu buku ini, juga menjadi ajang untuk mengevaluasi potensi cendekia yang terpendam di UIN Alauddin, dan tampak dengan antusiasme civitas akademik dalam menyambut program ini. Proses seleksi yang ketat hanya memungkinkan 250 penulis yang dapat berpartisipasi dan mampu menghasilkan buku dalam setiap tahun sejak tahun 2011 sampai $2014 .^{21}$

Konten buku-buku yang sukses diretas UIN melalui gerakan seribu buku sangat kaya dan variatif merepresentasikan mulai berjalannya integrasi kelimuan di UIN, sebab ternyata kajian-kajian yang terpapar dalam buku-buku tersebut bukan hanya disiplin ilmu agama, melainkan juga sains. Dan sebagian buku-buku tersebut telah menjadi bagian dari koleksi Library of Congress Kedutaan Besar Amerika Serikat.

${ }^{21}$ Hadi Daeng Mapuna, et.al, 2015. Mengukir Sejarah Peradaban 50 Tahun IAIN/UIN Alauddin, Makassar: UIN Press, hlm. 140 


\section{Peluang, Kelemahan, dan Kebijakan Strategis}

Hasil analisis SWOT berkenaan dengan kapasitas serta performa UIN panca transformasi institusional, dari sisi kekuataan (strength) yang saat ini inheren dalam tata kelola UIN. Setidaknya, terdapat enam domain yang menjadi titik kekuatan yang saat ini dimiliki UIN Alauddin sebagai organisasi pembelajar, terdiri dari: 1) Dari sisi branding yang bermuara pada daya tarik di mata stakeholders, UIN Alauddin merupakan Perguruan Tinggi Keagamaan Islam Negeri yang terkemuka di Kawasan Indonesia Timur, citra itu semakin mengalami peningkatan pasca transformasi institusional yang berikhtiar menjadikan institusi pendidikan tinggi ini sebagai pusat tranformasi ilmu pengetahuan par excellence, tak hanya berhenti di di situ, bidang seni pun menjadi lahan eksplorasi, dengan menjaga tipikalitasnya, yakni beralaskan peradaban Islam (Al-Tsaqafah alIslamiyah), pengarusutamaan integrasi dan interkoneksitas ilmu agama dan sains yang menjadi pembeda dari perguruan tinggi lainnya.

Kekuatan UIN ini semestinya membumi, Rasdiayanah, Mantan Dirjen Bimbaga Islam dan selama dua periode menakhodai IAIN Alauddin Makassar, mengartikulasikannya dengan afirmasi agar UIN Alauddin berkewajiban untuk ikut terlibat aktif serta konstruktif dalam proses pembangunan daerah yang berbasis agama dan ilmu pengetahuan. Dalam pengembangan keilmuan yang ditapaki, lanjut Rasdiayanah, UIN Alauddin juga harus mampu memberikan pencerdasan pencerahan, dan prestasi sesuai mottonya, sebagai bekal untuk kesuksesan pembangunan daerah. ${ }^{22}$

Tata Kelola organisasi secara profesional dan akuntabel yang mulai dirintis, dengan menjadikan manajemen mutu terpadu (Total Quality Management) sebagai benchmarking, baik pada aspek peningkatan kapasitas SDM, tata pamong, tata kerja. Di titik ini rekomendasi Andi Rasdiyanah menjadi penting, bahwa, perubahan substansial dan metodologis sudah banyak dilakukan UIN Alauddin melalui para manajemen organisasi. Namun, sesuai dengan paradigm perubahan tersebut, lanjut Rasdiyanah, UIN Alauddin tetap ditantang untuk tidak berpuas diri terhadap capaian kinerja tersebut, tetapi sejatinya konsisten menerapkan TQM. ${ }^{23}$ Meskipun sistem ini diderivasi dari dunia industri, tapi ternyata sudah mulai diterapkan di ranah pendidikan, sebagaimana diklaim $\mathrm{FEFC}^{24}$, kebanyakan perguruan tinggi sekarang mengakui perbaikan mutu terus-menerus adalah esensial agar tetap survive dan berhasil. Ini kerapkali direfefleksikan dalam pernyataanpernyataan dan rencana-rencana strategis dan operasional. Filosofi manajemen yang cukup familiar dan cocok bagi masyarakat di FE adalah manajemen mutu terpadu (TQM). Ia memiliki konsep perbaikan mutu secara berkelanjutan.

22 Rais, Muhammad, et.al. 2017. Dokumen Pemikiran Tokoh Pendidikan di Suilawesi Selatan, Makassar: Balitbang Agama, hlm. 21

23 Rasdiayanah, Andi, 2013. Revitalisasi dan Pemberdayaan Potensi UIN Alauddin: Peluang dan Tantangan, dalam Hadi (ed), Makassar: Alauddin Press, hlm. 363

24 Bush, Tony dan Marianne Coleman, 2012. Manajemen Mutu Kepemimpinan Pendidikan (Terj), Jogjakarta: IRCiSoD, hlm. 185 
Kekuatan lainnya yang kini direngkuh UIN input mahasiswa yang semakin membludak dari tahun ke tahun, melalui seleksi secara nasional. Selain itu tersedianya media pengembangan diri dalam bentuk kegiatan ilmiah, seni, kewirausahaan, olah raga, sehingga lahir karya-karya kreatif dan inovatif mahasiswa, serta dukungan teknologi dan informasi melalui akses internet, global net working yang sudah relatif memadai, yang membuka ruang penelusuran pustaka dan dukungan terhadap pengambilan kebijakan. Dan terakhir, jaringan alumni yang tersebar pada berbagai lini di dunia kerja baik di tingkat nasional maupun internasional yang sangat membantu pengembangan universitas.

Di sisi lain, UIN pun kini berada pada posisi yang tepat, sehingga menciptakan beberapa peluang, tinggal bagaimana manafaatkan peluang yang ada di depan mata tersebut, diantaranya semakin tingginya ekspektasi publik terhadap sumber daya manusia dengan kualitas penguasaan ipteks, sekaligus berperadaban Islam, berakhlak al-karimah. Hal ini tampak pada animo masyarakat dalam penerimaan calon mahasiswa baru yang membludak dari tahun ke tahun; tersedianya beasiswa dari luar instutisi UIN Alauddin bagi mahasiswa dengan latar belakang ekonomi lemah, namun mereka secara intelektual sangat prosfektif untuk berprestasi. Di sampan itu, reformasi memberikan dampak otonomi yang lebih luas kepada institusi, dan terbangunnya kerja sama dengan lembaga lain, baik di tingkat domestik maupun dengan luar negeri.

Di kutub lain, masih ditemukan beberapa kelemahan yang sejatinya dibenahi sehingga tidak berkepanjangan terjebak dalam pusaran kelemahan dan tantangan, diantaranya: 1) proses alih fungsi secara kelambagaan yang belum betul-betul rampung, terutama pada proyek integrasi keilmuan yang masih jalan di tempat, belum mememukan formula yang tepat; 2) Masih terkonsentrasinya program dan kegiatan pada salah satu komponen tridarma perguruan tinggi, yaitu mainstreaming aspek pendidikan, sehingga domain riset nyaris terabaikan, wajar saja, jika kemudian muncul sorotan berkenaan dengan masih terbatasnya publikasi karya ilmiah, baik dalam bentuk artikel di jurnal maupun dalam bentuk buku, apatah lagi jika sampai "bermimpi" untuk mendapatkan hak paten dalam waktu dekat. Aspek lain yang juga masih krusial adalah peningkatan mutu melalui akreditasi yang hingga kini masih tergolong rendah, baik akreditasi institusi maupun program studi yang masih perlu ditingkatkan. Sistem pendataan juga memperpanjang daftar kelemahan ini, sebab belum sepenuhnya terkoneksi antar unit kerja, sehingga setiap pengambilan kebijakan, belum sepenuhnya optimal.

Radiyanah mengafirmasi agar pihak pimpinan serta jajaran di UIN berkomitmen untuk peningkatkan akreditasi institusi maupun program studi yang saat ini masih dominan di akreditasi B bahkan masih banyak pula prodi yang terakreditasi $\mathrm{C}$. Kebijakan-kebijakan ini, lanjut Rasdiayanah, merupakan peluang sekaligus tantangan yang menggugah kemampuan untuk terwujudnya program studi yang lengkap di UIN Alauddin ${ }^{25}$.

25 Hadi Daeng Mapuna, et.al, 2015. Mengukir Sejarah Peradaban 50 Tahun IAIN/UIN Alauddin, Makassar: UIN Press, hlm. 364 
Dalam kerangka memanfaatkan peluang sekaligus mengatasi kelemahan serta tantangan yang inheren dalam perjalanan UIN Alauddin menggapai cita-citanya sebagaimana diterakan dalam visi, misi dan tujuannya, maka ada beberapa kebijakan strategis yang telah dirumuskan dan telah mulai diimplementasikan, baik di bidang organisasi dan kembagaan; ketenagaan; sarana dan prasarana; pembiayaan; pendidikan; perpustakaan; penelitian; pengabdian masyarakat; kemahasiswaan dan alumni; serta kerjasama.

Beranjak dari kondisi obyektif tersebut, program pengembangan kapasitas serta performa UIN ke depan, diarahkan pada dua hal yang diklaim sebagai strategic and priority programs, meliputi: 1) organisasi kelembagaan dan tata kelola; terdiri dari pembentukan lembaga Ortaker UIN Alauddin; 1) pembukaan fakultas ekonomi dan bisnis; fakultas kedokteran; pendirian rumah sakit pendidikan; serta penambahan prodi-prodi baru sesuai kebutuhan stakeholders. Upaya ini diikuti tata kelola organisasi yang professional, akuntabel serta transparan, agar kinerja organisasi lebih terarah, serta terukur; 2) pengembangan ketenagaan melalui upgrading dan training serta workshop ketenagaan; 3) tekruitmen tenaga edukasi, pustakawan, peneliti, laboran, operator komputer dan tenaga administrasi sehingga semuanya menjadi proporsional; 4) pengembangan di bidang pendidikan,

\section{PENUTUP}

Berdasarkan hasil reduksi, koding, serta kategorisasi data yang berhasil dikumpulkan melalui riset ini, dan bermuara pada analisis data yang mendeskripsikan kapasitas dan capaian kinerja UIN Alauddin pasca alihstatus, yang sebelumnya hanya fokus pada pengkajian dan pengembangan satu disiplin ilmu semata, tepatnya ilmu agama, yang cenderung monolitik dan atomistik, menjadi lebih interdisipliner dan integratif dengan dibukanya fakultas-fakultas eksakta, termasuk fakultas kedokteran yang terintegrasi dan terkoneksi dengan disiplin ilmu agama dan keagamaan. Dengan memanfaatkan metode kualitatif, penelitian ini menemukan bahwa, kapasitas UIN selama lebibh dari satu dasawarsa cukup mengalami peningkatan, baik dari sisi meningkatnya animo serta ekspektasi masyarakat terhadap UIN Alauddin yang ditandai semakin membludaknya peminat yang ingin menimba ilmu di intitusi pendidikan tinggi ini, selain itu semakin membaiknya tata kelola organisasi kelembagaan, ketenagaan, infrastruktur yang semakin kompetitif, pembiayaan yang semakin proporsional, pembelajaran, kerjasama, dan pengabdian masyarakat.

Meskipun demikian, dari sekian banyak capaian yang relatif menggembirakan di atas, tetap masih menyisakan beberapa kelemahan dan tantangan yang sifatnya masih krusial berkenaan denga proses transformasi institusional, terutama pada proyek integrasi dan interkoneksitas keilmuan yang masih "jalan di tempat"termasuk tantangan dari sisi mutu yang terejawantah pada akreditasi institusi maupun akreditasi yang direngkuh setiap program studi, yang akan berimplikasi pada keunggulan kompetitif maupuan keunggulan komparatif para lulusannya di dunia kerja, dan masih terbatasnya publikasi hasil-hasil penelitian, baik melalui jurnal 
nasional maupun internasional, maupun hasil-hasil kajian yang diartikulasi dalam bentuk buku daras.

\section{UCAPAN TERIMA KASIH}

Tulisan ini merupakan hasil penelitian tentang Kapasitas dan Performa UIN Alauddin Makassar Pasca Alih Status yang dibiayai oleh Balai Litbang Agama Makassar, penulis menyampaikan terima kasih kepada Kelapa Balai Litbang Agama Makassar atas perkenannya penulis terlibat dalam penelitian ini. Kepada seluruh pejabat, Dosen dan Mahasiswa di UIN Alauddin Makassar yang telah memberikan data dan informasi dalam penelitian, terima kasih pula disampaikan kepada Jurnal Edukasi yang telah berkenan mereview naskah ini sehingga bisa dimuat dalam jurnal ini.

\section{DAFTAR BACAAN}

Azhar, Arsyad, (2010): Sel Cemara: Integrasi dan Interkoneksitas Sains dan Ilmu Agama, dalam Nanath Fatah (ed), Yogyakarta, Pustaka Pelajar

Bourdieu, Pierre, (1993): The Field of Cultural Production, diterj. Yudi Santoso: Arena Produksi Kultural: Sebuah Kajian Sosiologi Budaya, Bantul, Kreasi Wacana

Bull, Ronald Lukens, (2013): Pendidikan Tinggi Islam di Indonesia di Persimpangan Jalan, Jakarta, Balitbang dan Diklat Kemenag RI

Bush, Tony dan Marianne Coleman, (2012): Manajemen Mutu Kepemimpinan Pendidikan (Terj), Jogjakarta, IRCiSoD
Creswell, John W, (2010): Research Design: Pendekatan Kualitatif, Kuantitatif, dan Mixed (Terj), Yogjakarta: Pustaka Pelajar

(2015): Penelitian Kualitatif dan Desain Riset: Memilih di antara Lima Pendekatan, Edisi III, Yogyakarta, Pustaka Pelajar

Ghafur, Hanief Sahar, (2009): Manajemen Mutu, Penjaminan dan Internasionalisasi Perguruan Tinggi di Indonesia, Jakarta, UI Press,

Lukito, Penny Kusumastuti Lukito, (2014): Membumikan Transparansi dan Akuntabilitas Kinerja Sektor Publik, Jakarta, Gramedia

Mapuna, Hadi Daeng et.al (ed), (2004): Langkah Pasti Menuju Universitas: Strategi dan Langkah Pencapaian UIN serta Catatan Tahun Kedua Masa Jabatan Arsyad Azhar, sebagai Rektor IAIN Alauddin), Makassar, Alauddin Press

(2015): Mengukir Sejarah Peradaban 50 Tahun IAIN/UIN Alauddin, Makassar, UIN Press

Maqdisi, George A, (2005): The Rise of Humanism in Classical Islam and The Christian West, diterj. A. Syansul Rizal: Cita Humanisme Islam: Panorama Kebangkitan Intelektual dan Budaya Islam dan Pengaruhnya terhadap Renainsans Barat, Jakarta, Serambi Ilmu

Mastuhu, (2003) Menata Ulang Pemikiran Sistem Pendidikan Nasional, Yogyakarta, Safiria Insania Press

(1999): Memberdayakan Sistem Pendidikan Islam, Ciputat, Logos Wacana Ilmu

Miles, Matthew dan A. Michael Huberman, (1999): Qualitative Data Analysis diterj. Tjetjep Rohendi Rohadi, Analisis Data Kualitatif: Buku Sumber tentang MetodeMetode Baru, Jakarta, UI Press 
Muhammadiyah, Hilmi, (2016): Review Hasil Pengawasan dan Audit Kinerja pada Balitbang Kemenag, disampaikan pada kegiatan Workshop RKAKL Balitbang Agama Makassar.

Musfah, Jejen, (2015): Manajemen Pendidikan: Teori, Kebijakan, dan Praktik, Jakarta, Prenada Media Utama.

Rais, Muhammad, et.al. (2017): Dokumen Pemikiran Tokoh Pendidikan di Suilawesi Selatan, Makassar, Balitbang Agama.
Rasdiayanah, Andi, (2013): Revitalisasi dan Pemberdayaan Potensi UIN Alauddin: Peluang dan Tantangan, dalam Hadi (ed), Makassar, Alauddin Press

Suharsaputra, Uhar, (2015): Majanemen Pendidikan Perguruan Tinggi: Strategi Menghadapi Perubahan, Bandung, PT Refika Aditama

Suparlan, (2013): Manajemen Berbasis Sekolahdari Teori sampai dengan Praktik, Jakarta, Bumi Aksara 